\title{
Inhibition of Angiogenesis and HIF-1 $\alpha$ Activity by Antimycin A1
}

\author{
Masayuki Maeda, Yuki Hasebe, Kiyoshi Egawa, Motoko Shibanuma, and Kiyoshi Nose* \\ Department of Microbiology, Showa University of Pharmaceutical Sciences; 1-5-8 Hatanodai, Shinagawa-ku, Tokyo \\ 142-8555, Japan. Received March 20, 2006; accepted March 27, 2006; published online April 3, 2006
}

\begin{abstract}
We identified antimycin A1 as an inhibitor of the hypoxia-response element (HRE) from screening using a reporter under the control of HRE under hypoxic conditions. Antimycin A1 was effective at $20 \mathrm{pg} / \mathrm{ml}$ in inhibiting the reporter activity. The expression of vascular endothelial growth factor (VEGF) mRNA during hypoxia was also inhibited by antimycin A1. Angiogenesis induced by implantation of mouse sarcoma-180 cells was significantly inhibited by non-toxic doses of antimycin A1. Hypoxia inducible factor (HIF)-1 $\alpha$ protein levels were significantly decreased by antimycin A1, but its mRNA level was not affected. Antimycin A1 is known to be an inhibitor of mitochondrial electron transport system, and depletion of mitochondria abolished antimycin A1-effect, at least in part. Inhibitors of proteasome or protein synthesis did not affect the decrease in HIF-1 $\alpha$ level induced by antimycin A1. These results indicate that antimycin A1 inhibited angiogenesis through decrease in VEGF production caused by inhibition of HIF-1 $\alpha$ activation.
\end{abstract}

Key words antimycin A1; hypoxia inducible factor (HIF)-1 $\alpha$; vascular endothelial growth factor (VEGF)

Angiogenesis is a key step during tumor progression, and the production of vascular endothelial growth factor (VEGF) plays a central role during this step. ${ }^{1)}$ Numerous types of tumors express high levels of VEGF, and VEGF participates in tumor progression by inducing angiogenesis. ${ }^{2-5)}$ Inhibitors of VEGF activity or its production are, thus, expected to be chemotherapeutic agents for cancer, and VEGF has become a molecular target in cancer chemotherapy. ${ }^{6-8)}$ Monoclonal antibody against VEGF (Bevasizumab, or Avastin) ${ }^{9-12)}$ is now used as an anti-angiogenic drug, and inhibitors of VEGF receptor tyrosine kinase also show anti-tumor activity. ${ }^{13-18)}$

Transcription of the VEGF gene is enhanced under hypoxic conditions and controlled primarily by hypoxia inducible factor 1 (HIF-1). ${ }^{19,20)}$ HIF-1 is a heterodimeric protein comprising of HIF- $1 \alpha$ and HIF- $1 \beta$, both of which are basic helix-loop-helix transcription factors. ${ }^{21)}$ Whereas HIF$1 \beta$ is constitutively expressed, HIF- $1 \alpha$ unstable under normoxic condition and is stabilized under conditions of hypoxia and activates hypoxia-inducible genes such as those for erythropoietin $^{22,23)}$ and VEGF. ${ }^{19,24)}$ The activity of HIF-1 $\alpha$ is mainly regulated by post-translational modifications. The oxygen-dependent degradation domain of HIF-1 $\alpha$ contains two proline residues at 402 and 564 that are hydroxylated by prolylhydroxylase. ${ }^{25,26)}$ This modification enables HIF-1 $\alpha$ to associate with von Hippel-Landau gene product (VHL), and this association stimulates ubiquitination of HIF- $1 \alpha$. Its rapid degradation under normoxic condition is catalized by a ubiquitin-proteasome. ${ }^{27-37)}$ HIF- $1 \alpha$ is stabilized under hypoxic condition due to decreased hydroxylation of prolin residues. $^{33,37)}$

We previously established a high through-put assay system using a stable transformant of mammalian cells that has incorporated the luciferase gene under the control of HRE. ${ }^{38)}$ Using this system from screening of bacterial culture fluids, we identified antimycin A1 that shows significant inhibition of reporter activity induced under hypoxic conditions and anti-angiogenic activity in vivo. In the present communication, we describe its modes of action against HIF- $1 \alpha$.

\section{MATERIALS AND METHODS}

Cell Culture A stable transformant of $\mathrm{CHO}$ cells (clone A4-4) was established by the transfection of HIF-1-dependent luciferase (5xHRE/pGL3/VEGF/E1b) and neomycin-resistant genes as described previously. ${ }^{39)}$ 10\%FBS Ham's F12 Human hepatoma (HepG2), lung cancer cells (A549) and HeLa S3 were cultured in Dulbecco's MEM (Hep G2 and A549) or RPMI 1640 (HeLa S3) medium supplemented with $10 \%$ fetal bovine serum. Cells were cultured at $37^{\circ} \mathrm{C}$ in $5 \%$ $\mathrm{CO}_{2}$ in humidified air. Under hypoxic conditions, cells were placed in a humidified chamber ventilated with a gas mixture of $5 \% \mathrm{CO}_{2}$ and $95 \% \mathrm{~N}_{2}$. The hypoxic state was confirmed as described previously. ${ }^{38)}$ Mitochondria-depleted A549 cells (A549 $\rho 0$ ) were established by isolating colonies formed after cultivation in DMEM supplemented with $10 \%$ fetal bovine serum, $4.5 \mathrm{~g} / 1$ glucose, $50 \mathrm{ng} / \mathrm{ml}$ ethidium bromide, $50 \mu \mathrm{g} / \mathrm{ml}$ uridine and $100 \mu \mathrm{M}$ pyrvate. ${ }^{40)}$

Luciferase Assay Cells were plated into 96-well tissue culture plates (Falcon) at a density of $1 \times 10^{4}$ cells/well, and treated with chemicals $16 \mathrm{~h}$ later. They were incubated further for $48 \mathrm{~h}$ under normoxic or hypoxic conditions, and harvested for the determination of luciferase activity. The assay was carried out using a kit provided by Promega Corp. (Madison, WI, U.S.A.) following the manufacturer's manual. Cytotoxicity was estimated by the MTT method as described previously. $^{41)}$

RNA Analysis For quantitative RT-PCR, $1 \mu \mathrm{g}$ of total RNA extracted with TRIzol reagent (Life Technologies, Inc., Rockville, MD, U.S.A.) was reverse-transcribed with random hexamer (Takara Shuzoh Co., Kyoto, Japan) and SuperScript ${ }^{\mathrm{TM}}$ II (Invitrogen, San Diego, CA, U.S.A.) in the presence of SYBER Green (Applied Biosystems Co.). Semiquantitative estimations of VEGF mRNA levels were performed using GeneAmp R5700 (PE Biosystems) with a primer set $\left(5^{\prime}\right.$-TGCAAAAACACAGACTCGCG, and $5^{\prime}$ TGTCACATCTGCAAGTACGTTCG), and a reference of $\beta$ actin (5'-CCTGGCACCCAGCACAAT and 5'-GGGCCGGACTCGTCATAC). For quantification of human Cytochrome b, a primer set (5'-CCCTCACACGATTCTTTACCTTTC and 5'-GTGCAAGAATAGGAGGTGGAGTG) was 
used.

For Northern blotting, total RNA was extracted with guanidium-hot phenol and samples of $20 \mu \mathrm{g}$ of RNA per lane were separated on agarose gel containing $2.2 \mathrm{M}$ formamide. The RNA was transferred to a nylon membrane and hybridized with a probe labeled by nick translation as described previously. ${ }^{41)}$ The probes (human VEGF and HIF-1 $\alpha$ cDNA) were prepared by a reverse transcription-polymerase chain reaction (RT-PCR) method using total RNA from HUVEC as a template and primers (5'-GAGTGTGTGCCCACTGAGGAGTCCAAC and 5'-CTCCTGCCCGGCTCACCGCCTCGGCTT) for VEGF, and (5'-GTAGTGCTGACCCTGCACTCAA and 5'-TCCATCGGAAGGACTAGGTGTC) for HIF- $1 \alpha$, and DNA fragments were cloned in a pGEM-T Easy vector. Glyceraldehyde phosphate dehydrogenase (GAPDH) cDNA was used as a reference. $\left.{ }^{41}\right)$

Western Blotting For immunoblotting, cells were washed with PBS and lysed in a RIPA buffer ( $50 \mathrm{~mm}$ Tris, $\mathrm{pH}$ $8.0,150 \mathrm{~mm} \mathrm{NaCl}, 1 \%$ Triton $\mathrm{X}-100,0.5 \%$ sodium deoxycholate, $0.1 \%$ SDS, $1 \mathrm{~mm}$ phenylmethylsulfonyl fluoride, and protease inhibitor mixture, Wako), and insoluble material was removed by centrifugation. Proteins were resolved by SDS-PAGE, transferred onto PVDF membranes, washed with PBS (10 mm Tris, $\mathrm{pH} 7.4$, and $100 \mathrm{~mm} \mathrm{NaCl}$ ), and blocked with blocking buffer (PBS containing 0.1\% Tween 20 and $1 \%$ BSA). Blots were incubated with anti-HIF- $\alpha$ antibody (BD Transduction Laboratories, $1: 250$ dilution) per $\mathrm{ml}$ for $1 \mathrm{~h}$ at room temperature. Horseradish peroxidase-conjugated secondary antibodies (Amersham Pharmacia Biotech) were used at $1: 10000$. Bound antibodies were visualized using an enhanced chemiluminescence detection system (Renaissance TM, New England Nuclear Life Science Products, Boston, MA, U.S.A.). Anti-glyceraldehyde dehydrogenase (Chemicon International) was used as a reference.

Assay of Mitochondrial Activity JC-1 (5,5',6,6' -tetrachloro-1,1',3,3' -tetraethyl-benzimidazolylcarbocyanine chloride, BioVision, Inc., Mountain View, CA, U.S.A. $10 \mu \mathrm{g} / \mathrm{ml}$ ) was mixed with conditioned medium and added to cells. After incubation at $37^{\circ} \mathrm{C}$ for $15 \mathrm{~min}$ in a $\mathrm{CO}_{2}$ incubator, cells were rinsed with HBSS and observed under a fluorescence microscope.

Dorsal Air Sac Assay (DAS Assay) A diffusion chamber covered with filters $(0.45 \mu \mathrm{m}$ pore size $)$ was filled with sarcoma-180 cells suspended in phosphate buffered saline $\left(1 \times 10^{7}\right.$ cells $\left./ \mathrm{ml}\right)$ and was implanted into dorsal air sacs created surgically by injection of an appropriate volume of air under the skin of male ICR mice. Five days after implantation, mice were sacrificed and angiogenesis around the chamber was observed under a microscope. Neovascularization was quantitated by measuring the number of newly formed vessels above the size of $3 \mathrm{~mm}$ in length and $0.05 \mathrm{~mm}$ in width. Five to six animals were used for each point. All animal experiments were conducted according to the "Guideline for Animal Experiments of Showa University Ethics Committee on Animal Experimentation.'

\section{RESULTS AND DISCUSSION}

Inhibition of HIF-1/Reporter Activity and VEGF Induction by Antimycin A1 We previously established a screening system to detect substances that affect the activity

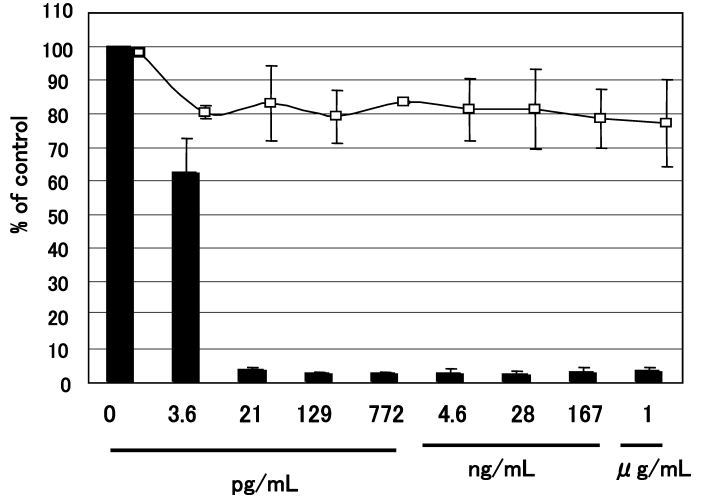

Fig. 1. Effect of Antimycin A1 on Reporter Activity Induced by Hypoxia

A4-4 cells were cultured in the presence of various concentrations of antimycin A1 for $16 \mathrm{~h}$ under hypoxic condition, and then luciferase activity (filled bars) and cell viability (open squares) were measured. Vertical bars represent standard deviations.

\section{A}

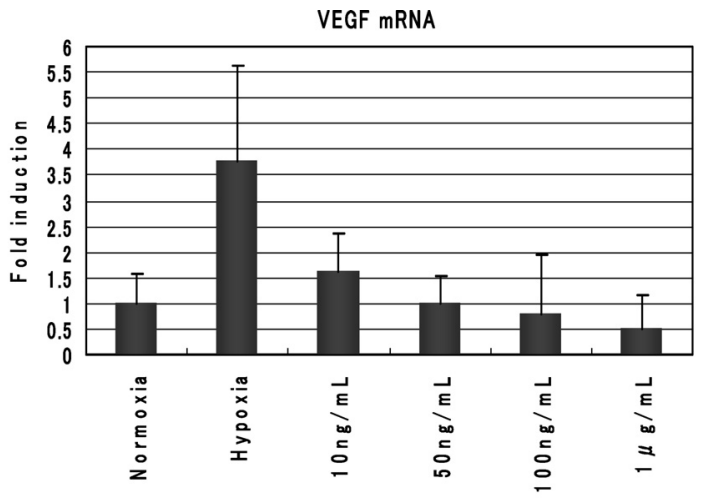

B

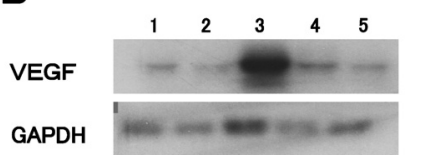

C

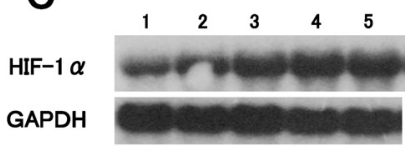

Fig. 2. Inhibition by Antimycin A1 of VEGF mRNA Expression during Hypoxia

(A) HepG2 were cultured under either normoxic or hypoxic condition for $16 \mathrm{~h}$ in the absence or presence of antimycin A1 at indicated concentrations. Total RNA was extracted, and relative amounts of VEGF mRNA were determined by real time RT-PCR (B, C) Northern blot hybridization. HepG2 cells that had been treated with antimycin A1 (lane 2, 4, 100 ng/ml; 5, 10 ng/ml) and cultured under normoxic (lane 1,2) or hypoxic (lane 3-5) conditions for $16 \mathrm{~h}$. Total RNA was isolated from HepG2 cells and subjected to Northern blot hybridization using probes indicated.

of HIF- $1 \alpha$. The CHO A4-4 cells were isolated by transfection of pSV2neo and 5xHRE/luciferase plasmids, and luciferase activity derived from the transfected reporter increased significantly under hypoxics condition as reported previously. ${ }^{39)}$ From screening of bacterial culture fluids (1600 species), antimycin A1 was identified to inhibit increase in reporter activity of HIF-1/luciferase that was induced under hypoxia at concentrations as low as $21.4 \mathrm{pg} / \mathrm{ml}$ Antimycin A1 is a well known inhibitor of mitochondrial electron transport system, but it did not show significant cytotoxicity at $1 \mu \mathrm{g} / \mathrm{ml}$ (Fig. 1).

Effect of Antimycin A1 on VEGF mRNA Expression The levels of VEGF mRNA were measured using HepG2 cells. Cells were cultured under hypoxic condition for $16 \mathrm{~h}$ in the absence or presence of antimycin A1, and VEGF mRNA levels were determined by real-time RT-PCR method or Northern blot hybridization. VEGF mRNA levels increased 
about four fold under hypoxia, and this increase was inhibited by antimycin A1 at $10 \mathrm{ng} / \mathrm{ml}$ (Fig. 2).

Inhibition of Angiogenesis in Vivo Inhibitory effect of antimycin A1 on angiogenesis in vivo was estimated by dorsal air sac method in mice. As shown in Fig. 3, angiogenesis was almost negligible with saline in the chamber, but potently induced by sarcoma-180 cells. Intra-peritoneal injection of antimyci A1 significantly inhibited sarcoma-180 induced angiogenesis $(p<0.05)$. Body weight of mice did not change significantly during the treatment period (data not shown).

Effect of Antimycin A1 on HIF-1 $\alpha$ Protein Levels As the expression of VEGF gene is mainly controlled by the level of HIF-1 $\alpha$, its protein levels were analyzed by Western blotting. Hep G2, HeLa S3 or A549 cells were cultured under hypoxia for $4 \mathrm{~h}$ in the absence or presence of antimycin A1, and HIF- $1 \alpha$ levels was determined by specific antibody. The results of Fig. 4 clearly show that antimycin A1-treat-

(a)

A

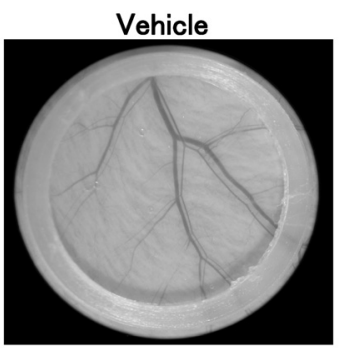

B

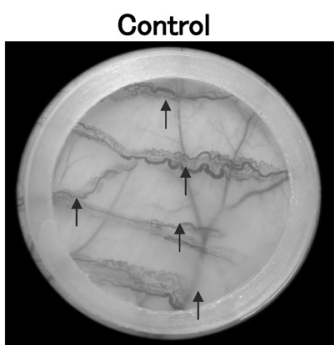

C
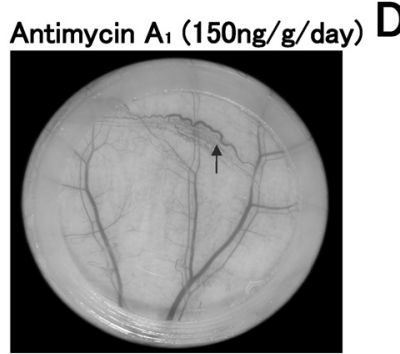

$\mathrm{D}$

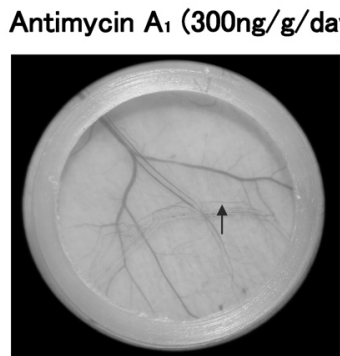

(b)

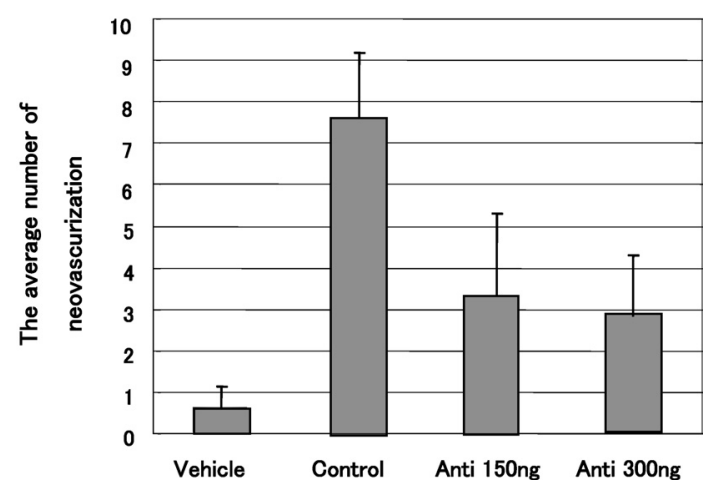

Fig. 3. Effect of Antimycin A1 on Angiogenesis in Vivo

(a) A-D, Illustration of angiogenic response induced by S180 sarcoma cells in ICR mice showing inhibitory effect of antimycin A1 administered for five consecutive days. A, Negative control group was implanted with chambers containing normal saline solution only. B, Positive control group was implanted with chambers containing S180 cells. C, and D, Antimycin A1 at a dose of $150 \mathrm{ng} / \mathrm{g} / \mathrm{d}$ or $300 \mathrm{ng} / \mathrm{g} / \mathrm{d}$ was administered intraperitoneally every day. Five days after implantation, chambers were excised and observed under a microscope. Arrows indicate the newly formed vessels. (b) Angiogenesis shown in $\mathrm{A}-\mathrm{D}$ was quantitated as described under Materials and Methods. Vertical bars indicate standard deviations. ment abolished increase in HIF-1 $\alpha$ levels in either cell type. Similar inhibition was observed when cells were treated with $\mathrm{CoCl}_{2}(100 \mu \mathrm{M})$ or an iron-chelator, deferoxamine $(100 \mu \mathrm{M})$ that stabilize HIF- $1 \alpha$ by depleting ferrous ion of prolylhydroxylase. HIF-1 $\alpha$ mRNA level was not affected significantly by antimycin A1 (Fig. 2C).

Effects of Antimycin A1 on HIF-1 $\alpha$ in MitochondriaDepleted Cells Antimycin A1 is well known inhibitor of complex III of mitochondria, and inhibits production of superoxide anion from mitochondria. To address a question whether the effect of antimycin A1 on HIF- $1 \alpha$ was dependent on mitochondrial function or not, mitochondria-depleted cells were isolated from A549 cells by cultivation in the presence of ethidium bromide. A549 $\rho 0$ cells thus established contained cytochrome $\mathrm{b}$ mRNA less than $10 \%$ of control cells (Fig. 5A), and mitochondrial membrane potential as determined by JC-1 staining was significantly decreased (data not shown). Decrease in HIF-1 $\alpha$ levels induced by antimycin A1 were significantly reduced in $\rho 0$ cells suggesting that the effect of antimycin A1 on HIF- $1 \alpha$ was mitochondria-dependent, at lease in part (Fig. 5B). HIF- $1 \alpha$ levels of $\rho 0$ cells in normoxia or hypoxia were significantly higher that those of control cells. Selak et at. reported that succinate that is utilized in TCA cycle of mitochondria inhibited prolyl hydroxylase, leading to stabilization of HIF-1 $\alpha{ }^{45)}$ This may be a reason for increased HIF- $1 \alpha$ levels of $\rho 0$ cells.

Mechanisms of Decrease of HIF-1 $\alpha$ by Antimycin A1 As prolyl hydroxylase requires molecular oxygen and ferrous ion, its activity is reduced not only under hypoxia but also in the presence of iron substitute such as $\mathrm{CoCl}_{2}$ or chelators and or deferoxamine induces stabilization of HIF- $1 \alpha^{25,36)}$ Hagen et al. recently reported that inhibitors of the mitochondrial electron transport induced redistribution of intracellular oxygen and activation of prolylhydroxylase. ${ }^{42)}$ Our results, how-

\section{A}
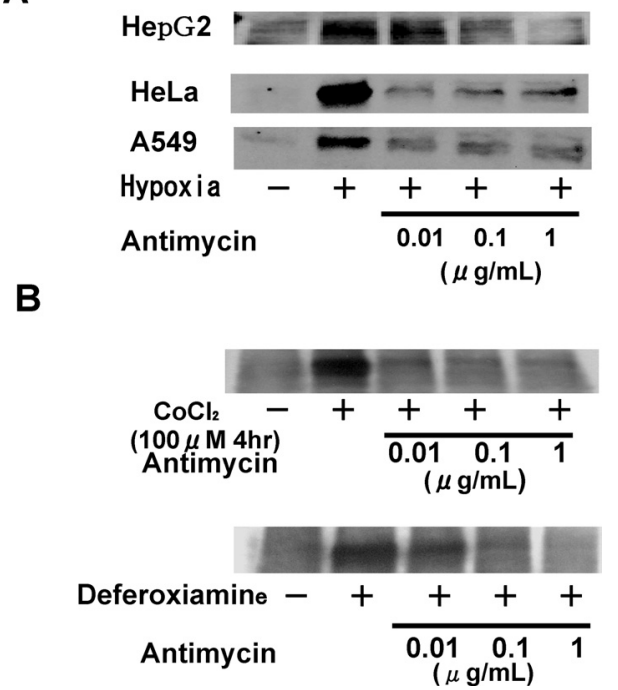

Fig. 4. Effect of Antimycin A1 on HIF-1 $\alpha$ Protein Levels under Hypoxia or Ferric Ion Deficiency

(A) HepG2, HeLa and A549 cells were treated with the indicated concentrations of antimycin A1 under normoxic or hypoxic conditions for $4 \mathrm{~h}$. Levels of HIF- $1 \alpha$ proteins were analyzed by Western blotting using anti-HIF-1 $\alpha$ antibody. (B) HepG2 cells were treated for $4 \mathrm{~h}$ with $100 \mu \mathrm{M} \mathrm{CoCl}_{2}$ (upper panel) or $100 \mu \mathrm{M}$ deferoxamine (lower panel) under normoxic conditions, with the indicated concentrations of antimycin A1. HIF- $1 \alpha$ levels were determined by Western blotting. Approximately $100 \mu \mathrm{g}$ of total cellular protein were loaded in each well. 
A

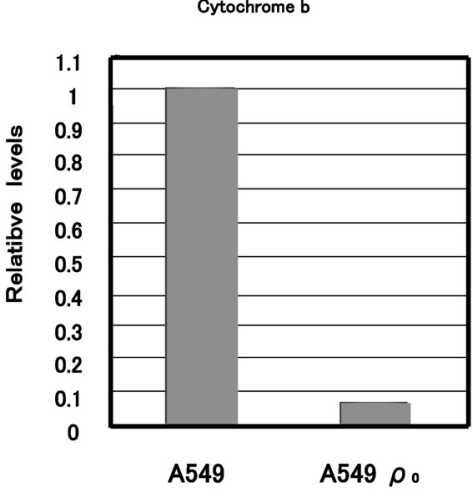

B

HIF-1 $\alpha$

A549

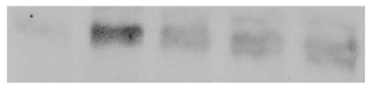

A549 $\rho_{0}$

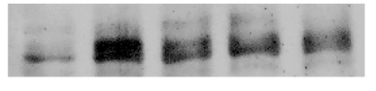

Hypoxia

(4hr)

Antimycin

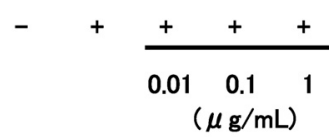

HIF-1 $\beta$

Fig. 5. Effect of Antimycin A1 in Mitochondrial DNA-Less Cells

(A) The mRNA levels of cytochrome b in wild or A549 $\rho 0$ cells were measured by real time RT-PCR. (B) A549 $\rho 0$ cells were treated with the indicated concentrations of antimycin A1 under normoxic or hypoxic conditions for $4 \mathrm{~h}$. Levels of HIF- $1 \alpha$ and HIF-1 $\beta$ proteins (A549 $\rho 0$ ) were analyzed by Western blotting.
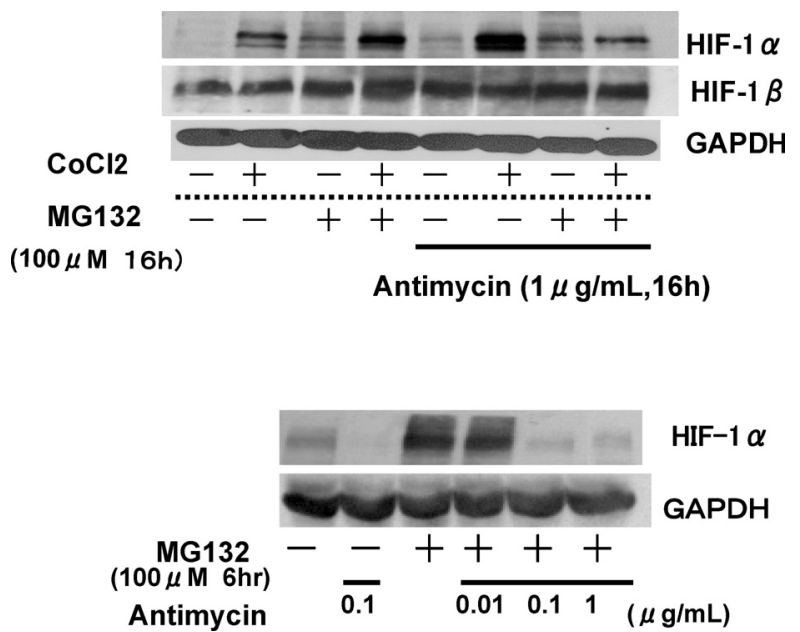

Fig. 6. Effect of a Proteasome Inhibitor on Antimycin A1-Effect

(A) HepG2 cells were pretreated for $4 \mathrm{~h}$ with $100 \mu \mathrm{M} \mathrm{CoCl}_{2}$ and were then treated with MG-132 $(100 \mu \mathrm{M})$ or antimycin A1 $(1 \mu \mathrm{g} / \mathrm{ml})$ for $60 \mathrm{~min}$. Cell lysates were prepared and subjected to Western blotting. The blotted filters were probed sequentially with anti-HIF- $1 \alpha$, anti-HIF-1 $\beta$ and anti-GAPDH antibody. Expression of HIF- $1 \alpha$ protein was quantitated by densimetry and was normalized to the value obtained in the corresponding GAPDH protein. (B) HepG2 cells were treated for $6 \mathrm{~h}$ with $100 \mu \mathrm{M}$ MG-132 under normoxic conditions, in the absence or presence of antimycin A1. HIF- $1 \alpha$ levels were determined by Western blotting. Approximately $100 \mu \mathrm{g}$ of total cellular protein were loaded in each well.

ever, that antimycin A1 reduced HIF- $1 \alpha$ levels increased by an ion chelator or $\mathrm{CoCl}_{2}$ indicate a mechanism other than oxygen redistribution.

HIF- $1 \alpha$ is an unstable protein and is rapidly degraded by proteasome. In order to examine involvement of proteasome in the decrease in HIF- $1 \alpha$ level in antimycin A1-treated cells, effect or proteasome inhibitor was examined. Hep G2 cells were cultured in the presence of $100 \mu \mathrm{M} \mathrm{CoCl}_{2}$ for $4 \mathrm{~h}$, and levels of accumulated HIF- $1 \alpha$ were measured $1 \mathrm{~h}$ later in the absence or presence of $1 \mu \mathrm{g} / \mathrm{ml}$ antimycin $\mathrm{A} 1$ and $100 \mathrm{~mm}$ proteasome inhibitor, MG-132. The results shown in Fig. 6 indicate that HIF-1 $\alpha$ levels were not different significantly between antimycin-treated and untreated cells in the presence of MG-132. This result suggests that proteasome does not participate in the decrease in HIF- $1 \alpha$ caused by antimycin-
A
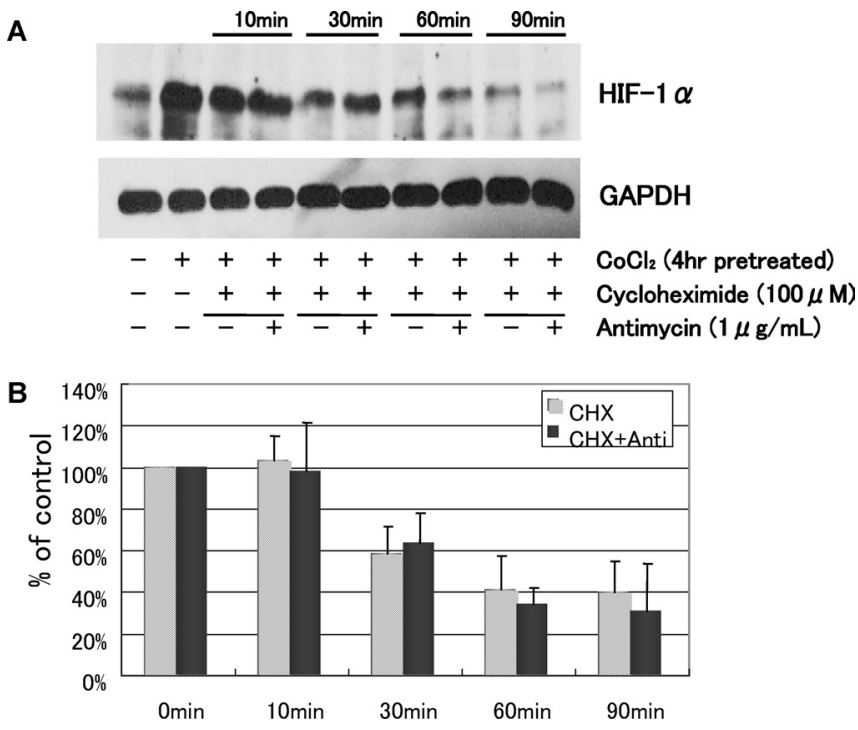

Fig. 7. Effect of Antimycin A1 on HIF- $1 \alpha$ Degradation

(A) HepG2 cells were pretreated for $4 \mathrm{~h}$ with $100 \mu \mathrm{M} \mathrm{CoCl}_{2}$. The cells were then treated with $100 \mu \mathrm{M}$ cyclohexamide (CHX) to block new protein synthesis, and were cultured in the absence (hatched bars) or presence (filled bars) of antimycin A1 for indicated times. (B) HIF-1 $\alpha$ levels shown in panel A were determined by densitometry, and relative amounts were estimated using GAPDH as a control. Vertical bars represent standard variations.

treatment.

Mode of action of antimycin A1 was supposed to be destabilization of HIF- $1 \alpha$ or inhibition of its synthesis. HIF- $1 \alpha$ protein levels in the presence of cyclohexide were analyzed. Hep $\mathrm{G} 2$ cells were treated with $\mathrm{CoCl}_{2}$ for $4 \mathrm{~h}$ to accumulate HIF-1 $\alpha$, and then cyclohexide and antimycin A1 was added. HIF-1 $\alpha$ protein levels were determined by Western blotting. The results shown in Fig. 7 indicate that degradation rate of HIF- $1 \alpha$ was not affected by antimycin A1. Levels of HIF- $1 \alpha$ mRNA did not change in antimycin A1-treated cells (Fig. $2 \mathrm{C}$ ). From these results, we speculate that antimycin A1-induced decrease in HIF-1 $\alpha$ levels was caused by inhibition of HIF- $1 \alpha$ protein synthesis.

Antimycin A1 is an inhibitor of complex III in mitochondria, and perturbations of mitochondrial functions will cause 
changes in levels and distribution of reactive oxygen species and other signaling pathways. ${ }^{44)}$ The results of Fig. 5, however, indicate that it decreased HIF-1 $\alpha$ levels even in mitochondria-depleted cells. At present, it is unclear how antimycin A1 affected HIF-1 $\alpha$ level, but the present study shows that it is a potent inhibitor of angiogenesis at doses far below the cytotoxic concentrations. Derivatives of antimycin A1 with less effect on mitochondrial and will be good candidate for anti-angiogenic agents.

Acknowledgements This study was supported in part by Grants-in-Aid for Scientific Research, a Grant-in-Aid for Cancer Research, and the High-Technology Research Center Project from the Ministry for Education, Culture, Sports, Science, and Technology of Japan.

\section{REFERENCES}

1) Shweiki D., Itin A., Soffer D., Keshet E., Nature (London), 359, 843845 (1992).

2) Plate K. H., Breier G., Millauer B., Ullrich A., Risau W., Cancer Res., 53, 5822-5827 (1993).

3) Mustonen T., Alitalo K., J. Cell Biol., 129, 895-898 (1995).

4) Zhong H., De Marzo A. M., Laughner E., Lim M., Hilton D. A., Zagzag D., Buechler P., Isaacs W. B., Semenza G. L., Simons J. W., Cancer Res., 59, 5830-5835 (1999).

5) Talks K. L., Turley H., Gatter K. C., Maxwell P. H., Pugh C. W., Ratcliffe P. J., Harris P. J., Am. J. Pathol., 157, 411-421 (2000).

6) Semenza G. L., Nat. Rev. Cancer, 3, 721-732 (2003)

7) Plate K. H., Breier G., Millauer B., Ullrich A., Risau W., Cancer Res., 53, 5822-5827 (1993).

8) Hajitou A., Sounni N. E., Devy L., Grignet-Debrus C., Lewalle J. M., Li H., Deroanner C. F., Lu H., Colige A., Nusgens B. V., Frankenne F., Maron A., Yeh P., Perricaudet M., Chang Y., Soria C., Calberg-Becq C. M., Foidart J. M., Noel A., Cancer Res., 61, 3450-3457 (2001).

9) Zondor S. D., Medina P. J., Ann. Pharmacother., 38, 1258-1264 (2004).

10) Willett C. G., Boucher Y., di Tomaso E., Duda D. G., Munn L. L., Tong R. T., Chung D. C., Sahani D. V., Kalva S. P., Kozin S. V., Mino M., Cohen K. S., Scadden D. T., Hartford A. C., Fischman A. J., Clark J. W., Ryan D. P., Zhu A. X., Blaszkowsky L. S., Chen H. X., Shellito P. C., Lauwers G. Y., Jain R. K., Nat. Med., 10, 145-147 (2004).

11) Price N., Clin. Colorectal Cancer, 4, 89-91 (2004).

12) Middleton G., Lapka D. V., Clin. J. Oncol. Nurs., 8, 666-669 (2004).

13) Lu D., Jimenez X., Zhang H., Wu Y., Bohlen P., Witte L., Zhu Z., Cancer Res., 61, 7002-7008 (2001)

14) Shaheen R. M., Tseng W. W., Davis D. W., Liu W., Reinmuth N., Vellagas R., Wieczorek A. A., Ogura Y., McConkey D. J., Drazan K. E., Bucana C. D., McMahon G., Ellis L. M., Cancer Res., 61, 1464 1468 (2001).

15) Laird A. D., Vajkoczy P., Shawver L. K., Thurnher A., Liang C., Mohammadi M., Schlessinger J., Ullrich A., Hubbard S. R., Blake R. A., Fong T. A., Strawn L. M., Sun L., Tang C., Hawtin R., Tang F., Shenoy N., Hirth K. P., McMahon G., Cherrington J. M., Cancer Res., 60 , 4152-4160 (2000).

16) Fong T. A., Shawver L. K., Sun L., Tang C., App H., Powell T. J., Kim Y. H., Schreck R., Wang X., Risau W., Ullrich A., Hirth K. P., McMahon G., Cancer Res., 59, 99-106 (1999).

17) Lin B., Podar K., Gupta D., Tai Y. T., Li S., Weller E., Hideshima T.,
Lentzsch S., Davies F., Li C., Weisberg E., Schlossman R. L., Richardson P. G., Griffin J. D., Wood J., Munshi N. C., Anderson K. C., Cancer Res., 62, 5019-5026 (2002).

18) Yeo E. J., Chun Y. S., Cho Y. S., Lee J. C., Kim M. S., Park J. W., J. Natl. Cancer Inst., 95, 516-525 (2003).

19) Forsythe J. A., Jiang B.-H., Iyer N. V., Agani F., Leung S. W., Koos R. D., Semenza G. L., Mol. Cell Biol., 16, 4605-4613 (1996).

20) Semenza G. L., Curr. Opin. Cell Biol., 13, 167-171 (2001).

21) Wang G. L., Semenza G. L., J. Biol. Chem., 270, 1230-1237 (1995).

22) Semenza G. L., Nejelt M. K., Chi S. M., Antonarakis S. E., Proc. Natl. Acad. Sci. U.S.A., 88, 5680-5684 (1991).

23) Beck I., Weinmann R., Caro J., Blood, 82, 704-711 (1993).

24) Semenza G. L., Genes Dev., 14, 1983-1991 (2000).

25) Bruick R. K., McKnight S. L., Science, 294, 1337-1340 (2001).

26) Huang L. E., Arany Z., Livingston D. M., Bunn H. F., J. Biol. Chem., 271, 32253-32259 (1996).

27) Cockman M. E., Masson N., Mole D. R., Jaakkola P., Chang G. W., Clifford S. C., Maher E. R., Pugh C. W., Ratcliffe P. J., Maxwell P. H., J. Biol. Chem., 275, 25733-25741 (2000).

28) Kamura T., Sato S., Iwai K., Czyzyk-Krzeska M., Conaway R. C., Conaway J. W., Proc. Natl. Acad. Sci. U.S.A., 97, 10430-10435 (2000).

29) Maxwell P. H., Wiesener M. S., Chang G. W., Clifford S. C., Vaux E. C., Cockman M. E., Wykoff C. C., Pugh C. W., Maher E. R., Ratcliffe P. J., Nature (London), 399, 271-275 (1999).

30) Ohh M., Park C. W., Ivan M., Hoffman M. A., Kim T. Y., Huang L. E., Pavletich N., Chau V., Kaelin W. G., Nat. Cell Biol., 2, 423-427 (2000).

31) Tanimoto K., Makino Y., Pereira T., Poellinger L., EMBO J., 19, $4298-4309$ (2000).

32) Ivan M., Kondo K., Yang H., Kim W., Valiando J., Ohh M., Salic A., Asara J. M., Lane W. S., Kaelin W. G., Jr., Science, 292, 464-468 (2001).

33) Jaakkola P., Mole D. R., Tian Y.-M., Wilson W. I., Gielbert J., Gaskell S. J., von Kriegsheim A., Hebestreit H. F., Mukherji M., Schofield C. J., Maxwell P. H., Pugh C. W., Peter J., Ratcliffe P. J., Science, 292, $468-472(2001)$.

34) Yu F., White S. B., Zhao Q., Lee F. S., Proc. Natl. Acad. Sci. U.S.A., 98, 9630-9635 (2001).

35) Yu F., White S. B., Zhao Q., Lee F. S., Cancer Res., 61, 4136-4142 (2001).

36) Epstein A. C. R., Gleadle J. M., McNeill L. A., Hewitson K. S., O’Rourke J., Mole D. R., Mukherji M., Metzen E., Wilson M. I., Dhanda A., Tian Y.-M., Masson N., Hamilton D. L., Jaakkola P., Barstead R., Hodgkin J., Maxwell P. H., Pugh C. W., Schofield C. J., Ratcliffe P. J., Cell, 107, 43-54 (2001).

37) Masson N., Willam C., Maxwell P. H., Pugh C. W., Ratcliffe P. J., EMBO J., 20, 5197-5206 (2001).

38) Hasebe Y., Egawa K., Nose K., Kunimoto S., Takeuchi T., Biol. Pharm. Bull., 26, 1379-1383 (2003).

39) Yamazaki Y., Egawa K., Nose K., Kunimoto S., Takeuchi T., Biol. Pharm. Bull., 26, 417-420 (2003).

40) King M. P., Attardi G., Methods Enzymol., 264, 304-313 (1996).

41) Egawa K., Nishigori H., Kunimoto S., Takeuchi T., Nose K., Biol. Pharm. Bull., 21, 899-904 (1998).

42) Hagen T., Taylor C. T., Lam F., Moncada S., Science, 302, 19751978 (2003).

43) Selak M. A., Armour S. M., MacKenzie E. D., Boulahbel H., Watson D. G., Mansfield K. D., Pan Y., Simon M. C., Thompson C. B., Gottlieb E., Cancer Cell, 7, 77-85 (2005).

44) Balaban R. S., Nemoto S., Finkel T., Cell, 120, $483-495$ (2005). 